\title{
Price Behavior of Chickpea in Major Markets of Marathwada
}

\author{
Shri. R. V. Chavan*, K. V. Deshmukh, S. S. More and R. D. Shelke \\ Department of Agricultural Economics, College of Agriculture, Parbhani, India \\ *Corresponding author
}

\begin{tabular}{|l|}
\hline Key w or d s \\
Price, Chickpea, \\
Major Markets, \\
Marathwada \\
\hline Article Info \\
\hline $\begin{array}{l}\text { Accepted: } \\
\text { 15 May } 2018 \\
\text { Available Online: } \\
\text { 10 June } 2018\end{array}$ \\
\hline
\end{tabular}

\section{A B S T R A C T}

Prices play an important role predominantly in agricultural economies like India. It determines not only what shall be produced but also how much to be produced. The objective of the present study is to study the market integration in selected markets of chickpea. The study was conducted in three major chickpea markets of Marathwada. Time series data of arrivals and prices of chickpea were collected from selected major markets. The monthly data of arrivals and prices were collected for the year 2002 to 2016. For analyzing, we have used the logarithmic transformation of monthly chickpea prices of selected markets. The data were collected from office record of respective Agricultural Produce Market Committee. The stationarity of time series data on chickpea prices was tested by applying the Augmented Dickey-Fuller test (ADF). Johansen's Multiple Cointegration test was employed to determine the long run relationship between the price series of selected markets. The Granger causality test was applied to study the price integration and to know the direction of causation between the selected markets. Vector Error Correction Model (VECM) was used to test the short run behavior of chickpea markets prices. The results showed that the chick pea prices series of all selected markets are at level are non-stationary and become stationary after first difference. In long run all markets are well integrated. Bidirectional causality is observed in all the selected markets. Short run equilibrium was observed in Hingoli market among all the selected markets. To attain the short run equilibrium in Parbhani and Latur markets, quick and live price information dissemination system should be developed.

\section{Introduction}

The price of agricultural product fluctuates more quickly as compared to the industrial product. So these changes in prices affect the income, standard of living of the farmer and rural population. Even these also affect the trade of other goods. Prices are the driving force for production of agricultural commodities; a stable price level would provide incentive to the producers to increase the production of required commodities thereby helping to achieve a balancing growth of the economy.

Efficient pricing of agricultural commodities, therefore, assumes a crucial role in initiating and maintaining the development process. It also leads to maximum social welfare from the given output. The objectives can be achieved only if the marketing system ensures prices, which are stable and remunerative to 
producers. The prices must be reasonable to consumers as well as to meet the demand for the increased production.

Prices play an important role predominantly in agricultural economies like India. It determines not only what shall be produced but also how much to be produced. The price system is a powerful tool to transmit essential economic information and stimulate appropriate decision by producers and consumers. Price is the most important determinant of profit or loss in the farm enterprise. In farm enterprise, time factor is very important, where crops are grown in one period, and harvested in another period. Therefore, the prices prevailing during the marketing period are of great consequence.

The main objectives include to study the market integration in selected markets of chickpea

\section{Data}

The study was conducted in three major chickpea markets of Marathwada. Time series data of arrivals and prices of chickpea were collected from selected major markets. The monthly data of arrivals and prices were collected for the year 2002 to 2016. For analyzing, we have used the logarithmic transformation of monthly chickpea prices of selected markets. The data were collected from office record of respective Agricultural Produce Market Committee.

\section{Analytical techniques}

\section{Market integration}

\section{Testing of stationary}

Before analyzing any time series data testing for stationarity is pre-requisite. The stationarity of time series data on chickpea prices was tested by applying the Augmented Dickey-Fuller test (ADF). The ADF test is the test for the unit root in a time series sample. A stationary series is one whose parameters are independent of time, exhibiting constant mean and variance and having autocorrelations that are invariant through time. If the series is found to be non-stationary, the first differences of the series are tested for stationary. The number of times (d) a series is differenced to make it stationary is referred to as the order of integration, I (d)

$\mathrm{ADF}$ unit root test are based on the following three regression forms:

Without constant and trends $\Delta \mathrm{Y}_{\mathrm{t}}=\delta \mathrm{Y}_{\mathrm{t}-1}+\mathrm{u}_{\mathrm{t}}$

With constant $\Delta \mathrm{Y}_{\mathrm{t}}=\alpha+\beta \mathrm{T}+\Delta \mathrm{Y}_{\mathrm{t}-1}+\mathrm{u}_{\mathrm{t}}$

With constant and trend

The hypothesis is:

Ho: $\delta=0$ (unit root)

$\mathrm{H}_{1}: \delta \neq 0$

If $t^{*}>$ ADF critical value then accept the Null hypothesis, i.e. unit root exists and

If $t^{*}<A D F$ critical value then reject the Null hypothesis, i.e. unit root does not exists.

\section{Co-integration}

Johansen's Multiple Co-integration test was employed to determine the long run relationship between the price series of selected markets. The test shows whether the selected green gram markets are integrated or not. Johansen (1988) has developed a multivariate system of equations approach, which allows for simultaneous adjustment of both or even more than two variables. The multivariate systems of equations approach are more efficient than single equation 
approach since it allows estimating the cointegration vector with smaller variance. The second advantage of the multivariate approach is that in the simultaneous estimation it is not necessary to presuppose erogeneity of either of the variables.

\section{Causality}

The Granger causality test was applied to study the price integration and to know the direction of causation between the selected markets. It is named after the first causality tests performed by Clive Granger (1969). It analyses the extent to which the past variations of one variable explain (or precede) subsequent variations of the other. When a cointegration relationship is present for two variables, a Granger Causality Test can be used to analyze the direction of this comovement relationship. Granger causality tests come in pairs, testing weather variable $\mathrm{x}_{\mathrm{t}}$ Granger causes variable $y_{t}$ and vice versa. All permutations are possible:

Univariate Granger causality from $x_{t}$ to $y_{t}$ or from $y_{t}$ to $x_{t}$

Bivariate causality or absence of causality.

Theoretically, a variable is said to Granger cause another variable, if the current value is conditional on the past value.

\section{Short run equilibrium}

Vector Error Correction Model (VECM) was used to test the short run behavior of chickpea markets prices. Even if one demonstrates market integration through co-integration, there should be disequilibrium in the short run i.e. price adjustment across markets may not happen instantaneously. It may take some time for the special price adjustments. Error correction model can incorporate such shortrun and long-run changes in price movement.
A generalized VECM formulation to understand both the short-run and long-run behaviour of prices can be considered by first taking the autoregressive distributed lag (AdL). The generalized form of this equation for $\mathrm{k}$ lags and an intercept term is as follows:

$\Delta \mathrm{Y}_{\mathrm{t}}=\mathrm{a}_{00}+\sum \mathrm{a}_{\mathrm{i}} 1 \Delta \mathrm{x}_{\mathrm{t}-1}+\mathrm{m}_{0}\left[\mathrm{~m}_{1} \mathrm{x}_{\mathrm{t}-\mathrm{k}}-\mathrm{y}_{\mathrm{t}-\mathrm{k}}\right]+\varepsilon_{\mathrm{t}}$

Where,

$\mathrm{M}_{0}=\left(1-\mathrm{a}_{\mathrm{i}} 2\right)$

The parameter $m_{0}$ measures the rate of adjustment of the short-run deviations towards the long-run equilibrium. Theoretically, this parameter lies between 0 to -1 . The value 0 denotes no adjustment and -1 indicate an instantaneous adjustment. A value between 0 to -1 indicates that any deviations will have gradual adjustment to the long-run equilibrium values.

\section{Results and Discussion}

\section{Market integration among major chickpea markets}

Market integration explains the relationship between two markets that are spatially separated. One of the important indicators of efficient functioning of market is that the markets should be spatially integrated. Integrated markets are those where the prices are determined independently. If the markets located at different places are not integrated, there will be wide differences among the prices in different markets which cannot be explained by transport costs.

In integrated markets, price of commodity is responsible to price changes of same quality product in other markets, as such price differences for particular variety of product in different markets of area, should not exceed the cost involved in the transportation and 
handling of the produce. To check whether the prices are stationary in markets under study or not, the Augmented Dickey-Fuller (ADF) test was employed. To determine the long run relationship between the price series or to test whether the selected chickpea markets are integrated or not, the Johansen's multiple cointegration tests was employed. In order to know the direction of causation between the markets Granger Causality test was employed. To understand both the short run and long run behavior of prices, the Vector Error Correction model was employed. The results of the same are as follows.

\section{Testing stationary in price series}

The Augmented Dickey-Fuller (ADF) test based on unit root test produce was carried out to check whether chickpea prices are stationary in the selected markets. The test was applied for Parbhani, Hingoli and Latur markets during the period of 2002 to 2016 and the results are presented in table 1. From the table it is observed that, at level with lag one, the ADF values of Parbhani (-2.24), Hingoli (1.84) and Latur (-0.22) more than the critical value at one per cent $(1 \%)$ level of significance indicating the existence of unit root implied that the price series of three markets namely Parbhani, Hingoli and Latur are non-stationary. The table further showed that in first difference with lag one, the Augmented Dickey- Fuller (ADF) values of Parbhani (-5.46), Hingoli (-6.10) and Latur market (-6.03) are lower than that of the critical value at one per cent level this implied that the prices series become stationary at first difference level.

Table.1 ADF test results of chickpea prices

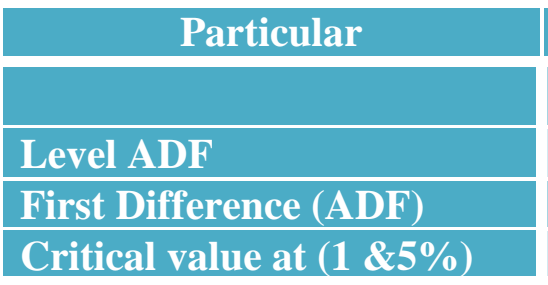

\begin{tabular}{|c|c|c|}
\hline \multicolumn{2}{|c|}{ Markets } & \\
\hline Parbhani & Hingoli & Latur \\
\hline$-2.24(0.47)$ & $-1.84(0.64)$ & $-0.22(0.99)$ \\
\hline$-5.46(0.01)$ & $-6.10(0.01)$ & $-6.03(0.01)$ \\
\hline & -3.46 and -2.87 & \\
\hline
\end{tabular}

Table.2 Multiple co-integration analysis of chickpea prices

\begin{tabular}{|c|c|c|c|c|c|}
\hline \multicolumn{2}{|c|}{ No. of co-integration equation } & \multicolumn{4}{|c|}{ Eigen and trace values } \\
\hline $\begin{array}{c}\text { Null } \\
\text { hypothesis }\end{array}$ & Alternative hypothesis & Eigen value & Trace value & Critical value at $5 \%$ & Critical value at $1 \%$ \\
\hline$r=0$ & $r=1$ & $86.47 *$ & 144.31 & 21.07 & 25.75 \\
\hline$r=1$ & $r=2$ & $57.59 *$ & 57.84 & 14.90 & 19.19 \\
\hline $\mathrm{r}=\mathbf{2}$ & $r=3$ & $0.25^{\mathrm{NS}}$ & 0.25 & 08.18 & 11.65 \\
\hline
\end{tabular}

Trace test indicates two co-integrating equation at 0.01 level

Table.3 Pair wise Granger Causality test for chickpea prices for selected Markets

\begin{tabular}{|l|c|c|c|}
\hline \multicolumn{1}{|c|}{ Null Hypothesis } & Observation & F-Statistic & Probability \\
\hline Latur does not Granger Cause Hingoli & 178 & 8.74853 & 0.01 \\
\hline Hingoli does not Granger cause Latur & & 21.2678 & 0.01 \\
\hline Parbhani does not Granger cause Hingoli & 178 & 8.17739 & 0.01 \\
\hline Hingoli does not Granger cause Parbhani & & 20.7288 & 0.01 \\
\hline Parbhani does not Granger Cause Latur & 178 & 11.5807 & 0.01 \\
\hline Latur does not Granger Cause Parbhani & & 10.1564 & 0.01 \\
\hline
\end{tabular}


Table.4 Vector Error Correction model of chickpea prices in selected markets

\begin{tabular}{|c|c|c|c|}
\hline Error Correction & D(In Parbhani) & D(In Hingoli) & D(In Latur) \\
\hline \multirow[t]{3}{*}{ CointEq1 } & 0.374362 & -0.239403 & 0.0533904 \\
\hline & $(0.09037)$ & $(0.11875)$ & $(0.13489)$ \\
\hline & [4.14277] & {$[-2.01605]$} & [3.95816] \\
\hline \multirow[t]{3}{*}{ D(In_Parbhani (-1)) } & -0.065025 & -0.157018 & -0.041833 \\
\hline & $(0.07862)$ & $(0.10331)$ & $(0.11736)$ \\
\hline & {$[-0.82708]$} & {$[-1.51981]$} & {$[-0.35646]$} \\
\hline \multirow[t]{3}{*}{ D(In_Parbhani (-2)) } & 0.191562 & 0.0883305 & -0.045152 \\
\hline & $(0.07381)$ & $(0.09700)$ & $(0.11018)$ \\
\hline & [2.59527] & {$[0.85885]$} & {$[-0.40981]$} \\
\hline \multirow[t]{3}{*}{ D(Hingoli (-1)) } & -0.257072 & -0.025922 & -0.348983 \\
\hline & $(0.08549)$ & $(0.11234)$ & $(0.12760)$ \\
\hline & {$[-3.00717]$} & {$[-0.23075]$} & {$[-2.73488]$} \\
\hline \multirow[t]{3}{*}{ D(In_Hingoli (-2)) } & -0.074035 & -0.176495 & -0.050475 \\
\hline & $(0.07819)$ & $(0.10274)$ & $(0.11671)$ \\
\hline & {$[-0.94690]$} & {$[-1.71780]$} & {$[-0.43248]$} \\
\hline \multirow[t]{3}{*}{ D(In_Latur (-1)) } & -0.43325 & 0.044389 & -0.110886 \\
\hline & $(0.06649)$ & $(0.08737)$ & $(0.09924)$ \\
\hline & {$[-0.65165]$} & {$[0.50807]$} & {$[-1.11733]$} \\
\hline \multirow[t]{3}{*}{ D(In_Latur (-2)) } & -0.068596 & -0.100817 & -0.260143 \\
\hline & $(0.05549)$ & $(0.07292)$ & $(0.08283)$ \\
\hline & {$[-1.23620]$} & {$[-1.38261]$} & {$[-3.14077]$} \\
\hline $\mathrm{C}$ & --- & --- & --- \\
\hline R-Squared & 0.295126 & 0.186077 & 0.343551 \\
\hline Adj. R-Squared & 0.152364 & 0.152364 & 0.316361 \\
\hline Sum Sq. resids & 23827148 & 41145878 & 53089747 \\
\hline S.E. equation & 375.4851 & 493.4235 & 560.4824 \\
\hline F-Statistic & 10.10844 & 5.519479 & 12.63509 \\
\hline Log Likelihood & -1296.354 & -1344.701 & -1367.256 \\
\hline Akaike AIC & 15.53962 & 15.28476 & 14.73846 \\
\hline Schwarz SC & 15.68317 & 15.42831 & 14.88201 \\
\hline Mean dependent & 36.55367 & 29.26554 & 32.17514 \\
\hline S.D. dependent & 677.8731 & 535.9388 & 438.2520 \\
\hline
\end{tabular}




\section{Market Co-integration}

Johansen's multiple Co-integrations test is employed to determine the long run relationship between the price series of chickpea. Co-integration is used instead of regular regression method because of its capacity in dealing with non-stationary series.

The most popular Co-integration method developed by Johansen (1988) and Johansen and Juselius (1990) was applied. The test shows whether the selected chickpea markets are integrated or not. The results of the test were presented in table 2 .

Presence of two co-integration equation at five per cent level of significance confirms that there exists long run equilibrium relation in the market. Likewise, from the table it is revealed that the results of Co-integration test showed one co-integration equation was significant at five per cent level of significance. It indicated that the selected chickpea markets having long run equilibrium relationship and there exists Co-integration between them.

\section{Causality of price signals between selected markets}

Granger Causality test is a statistical tool which used F-test to know the cause and effect relationship between the three time series of selected chickpea markets. When a co-integration relationship is present for three price series, a Granger Causality test is used to analysis the direction of this co-movement relationship.

The results of the test showing the relationship between selected chickpea markets were presented in table 3. It was observed that there is bidirectional causality in chickpea prices between Parbhani, Hingoli and Latur markets.

\section{Short run and long run behavior of market prices}

Since the Johansen's multiple co-integration test results showed that the selected chickpea markets having long run equilibrium relationship and there exists co-integration between them. Hence the Vector Error Correction model (VECM) among the selected markets of chickpea is employed to know the speed of adjustments for the prices of chickpea among selected markets, for short run and long run equilibrium of prices. The results of VECM showed in table 5. From the table of estimates of VECM revealed that, Hingoli markets attained short run equilibrium rapidly.

The chick pea prices series of all selected markets are at level are non-stationary and become stationary after first difference. In long run all markets are well integrated. Bidirectional causality is observed in all the selected markets. Short run equilibrium was observed in Hingoli market among all the selected markets.

\section{Policy Implication}

To attain the short run equilibrium in Parbhani and Latur markets, quick and live price information dissemination system should be developed.

\section{References}

Bhende, M.J., 2012. Market integration of major agriculture markets in Karnataka: An empirical study of selected commodities. Report submitted to Agricultural development and rural transformation centre, Institute for Social and Economic Change, Bangalore. 1-105

Chaudhari, D.J. and A.S. Tingre, 2012. Pigeonpea (Cajanus cajan L.) price 
movement across major markets of India. Journal of Food Legumes, 25(4): 344-347.

Mayaka, V.K., 2013. An assessment of dry beans market integration in selected markets in Kenya. Thesis submitted to the Graduate school, in Agriculture and Applied Economics, Egerton University, Kenya.

Meena, D. C., Hosamani, N. R. Mamledesai, 2011.Price behaviour and market integration of Rapeseed-mustard in
Rajasthan. Karnataka J. Agric. Sci., 24 (3): 408-409.

Moe, A. K., T. Yutaka, S. Fukuda and S. Kai, 2008. Impact of Agricultural Market Reform on Pulses Market Integration in Myanmar. J. Fac. Agr., Kyushu Univ., 53(1):337-347.

Tingre, A.S., A.A. Bhopale and R.G. Deshmukh, 2016. Price stability of soybean for major markets of India. International Research Journal of Agricultural Economics and Statistics, 7(2): 169-174.

\section{How to cite this article:}

Shri. R. V. Chavan, K. V. Deshmukh, S. S. More and Shelke R. D. 2018. Price Behavior of Chickpea in Major Markets of Marathwada. Int.J.Curr.Microbiol.App.Sci. 7(06): 1359-1365. doi: https://doi.org/10.20546/ijcmas.2018.706.160 